\title{
Proposed Lake Arthur Detention Basin Expansion City of Port Arthur, Jefferson County, Texas
}

Michael Hogan

Jennifer Hatchett Kimbell

Follow this and additional works at: https://scholarworks.sfasu.edu/ita

Part of the American Material Culture Commons, Archaeological Anthropology Commons, Environmental Studies Commons, Other American Studies Commons, Other Arts and Humanities Commons, Other History of Art, Architecture, and Archaeology Commons, and the United States History Commons

Tell us how this article helped you.

This Article is brought to you for free and open access by the Center for Regional Heritage Research at SFA ScholarWorks. It has been accepted for inclusion in Index of Texas Archaeology: Open Access Gray Literature from the Lone Star State by an authorized editor of SFA ScholarWorks. For more information, please contact cdsscholarworks@sfasu.edu. 
Proposed Lake Arthur Detention Basin Expansion City of Port Arthur, Jefferson County, Texas

\section{Creative Commons License}

\section{(c) (1) \&}

This work is licensed under a Creative Commons Attribution-NonCommercial 4.0 International License 


\section{Cultural Resources Survey}

PROPOSED LAKE ARTHUR DETENTION BASIN EXPANSION CITY OF PORT ARTHUR, JEFFERSON COUNTY, TEXAS

November 21, 2019

Terracon Project No. 92197231

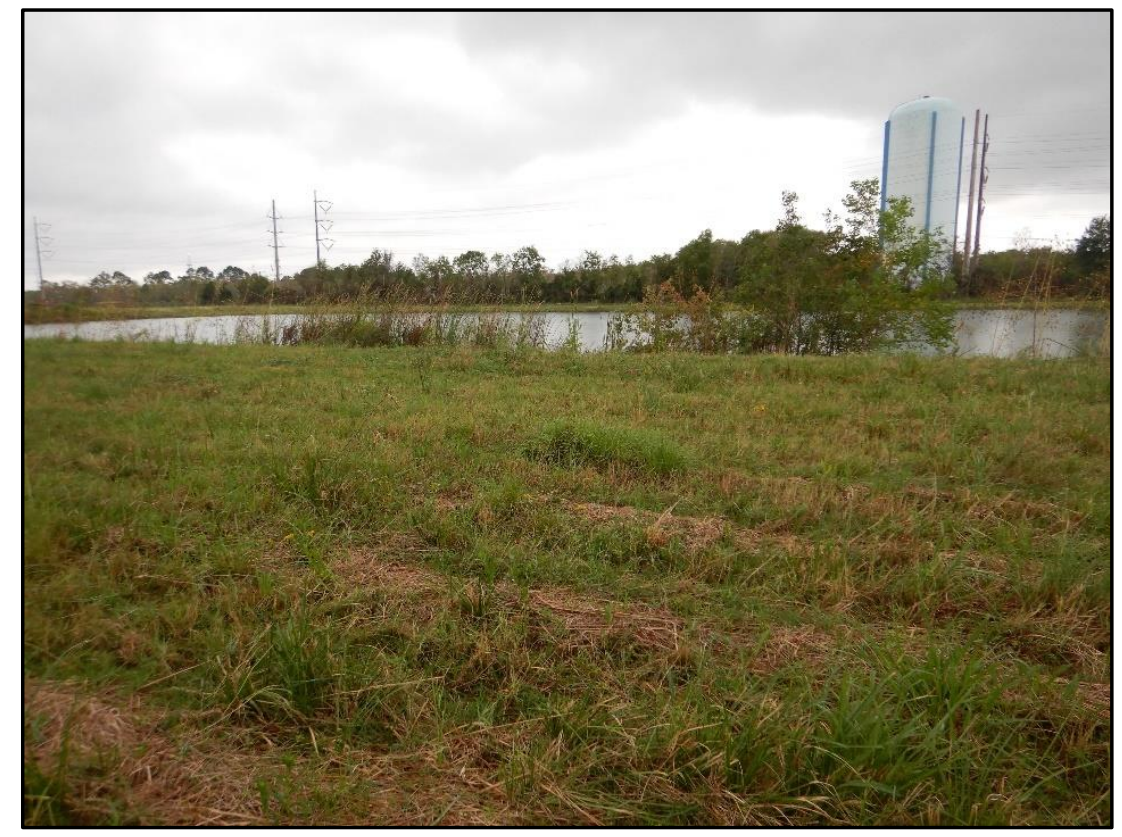

Prepared for: City of Port Arthur Port Arthur, Texas

Prepared by: Michael Hogan, MA and Jennifer Hatchett Kimbell, MA, RPA Terracon Consultants, Inc. Houston, Texas

Principal Investigator: Jennifer Hatchett Kimbell, MA, RPA TAC Permit No. 9109 


\section{ABSTRACT}

Terracon Consultants, Inc. (Terracon) was contracted by the City of Port Arthur (client) to conduct a cultural resources survey of an approximately 54-acre project area in Port Arthur, Jefferson County, Texas in advance of the proposed expansion of an existing detention basin. Since the proposed undertaking will occur on land owned or controlled by a political subdivision of the State of Texas, and because funding for this project will come, in part, from the Federal Emergency Management Agency (FEMA), this project required compliance with the Antiquities Code of Texas (Texas Natural Resources Code Chapter 191) and its implementing rules and regulations (Texas Administrative Code Chapter 26) and Section 106 of the National Historic Preservation Act (NHPA), (54 USC § 306101) and its implementing rules and regulations, 36 CFR 800. This project was conducted under Antiquities Permit \#9109.

The proposed project area comprises a 54-acre tract of land located between Texas State Highway 347 and U.S. Route 69 in Port Arthur, Texas. Terracon archeologists excavated a total of eleven (11) shovel tests to a depth of 80 centimeters $(\mathrm{cm})$ below surface, or to sediments inferred to predate human occupation in the area. The removed sediment was passed through $1 / 4$-inch hardware mesh to screen for artifacts. No cultural materials were identified during the survey. Additionally, to comply with Section 106 of the NRHP, adjacent parcels were evaluated to determine whether historic properties might be present and subject to visual effects from the project. No such historic properties were identified. Fieldwork was conducted between October 15 and October 17, 2019 by Michael Hogan (Staff Archeologist) and Amani Bourji (Field Technician) under the supervision of Jenni Hatchett Kimbell (Principal Investigator). The report was authored by Michael Hogan and Jenni Hatchett Kimbell.

Given the absence of known prehistoric or historical-period resources within the proposed project area, Terracon recommends that the expansion of the Lake Arthur detention basin proceed as planned. Should human remains, historic properties, or buried cultural materials be encountered during construction or disturbance activities, work should cease in the immediate vicinity and Terracon, the Texas Historical Commission (THC) Archeology Division, or other proper authorities should be contacted. 


\section{TABLE OF CONTENTS}

ABSTRACT

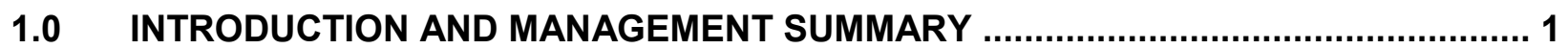

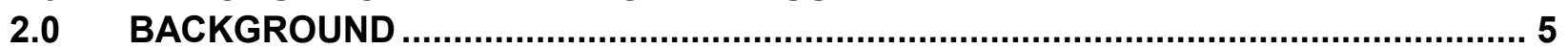

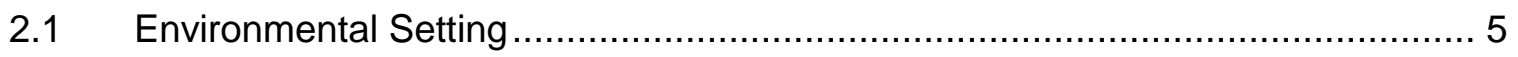

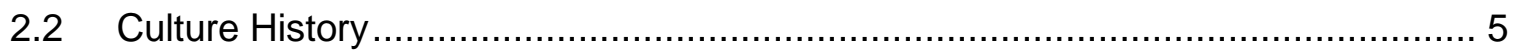

3.0 RESEARCH AND SURVEY METHODS ……........................................................ 7

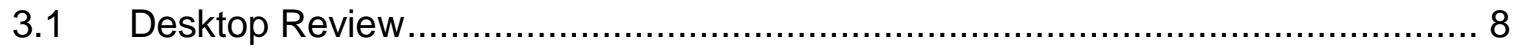

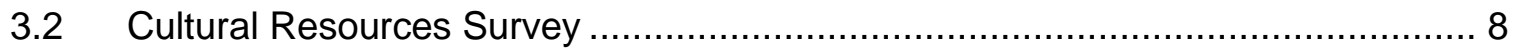

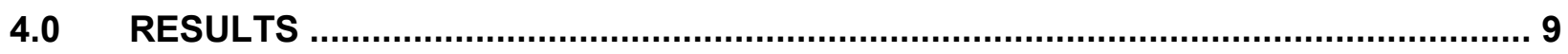

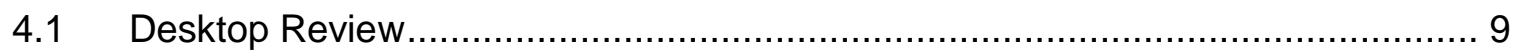

$4.2 \quad$ Cultural Resources Survey ................................................................12

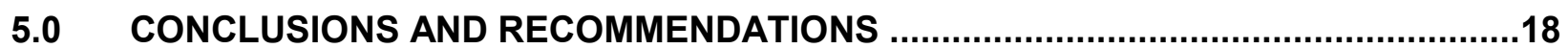

\section{List of Figures}

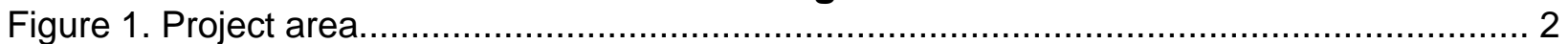

Figure 2. Project area on 2019 Port Arthur North USGS 7.5' quadrangle................................. 3

Figure 3. Project area land parcels and areas.............................................................. 4

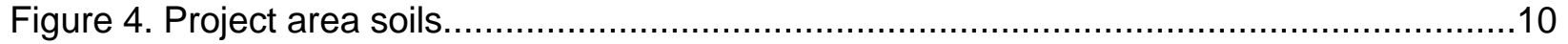

Figure 5. Results of the desktop assessment............................................................11

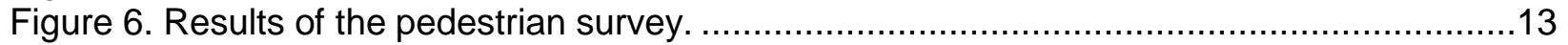

Figure 7. Excavation of shovel test IP10 in Area 2 (facing northeast)...................................14

Figure 8. Excavation of shovel test IP12 in Area 2 (facing west). ......................................14

Figure 9. Vegetation in the northernmost land parcel, Area 1 (facing northwest)......................15

Figure 10. Vegetation in the northernmost land parcel, Area 1 (facing southwest). ..................15

Figure 11. Vegetation in the central land parcels, Area 2 (facing west). ..............................16

Figure 12. Vegetation in the central land parcels, Area 2 (facing east) .................................16

Figure 13. Vegetation in the southern land parcel, Area 3 (facing south) ................................17

Figure 14. Vegetation in the southern land parcel, Area 3 (facing west) .................................18

\section{List of Tables}

Table 1. Generalized culture history for Southeast Texas, with corresponding environmental periods.

\section{Appendix \\ Investigation Point Log}




\title{
CULTURAL RESOURCES SURVEY OF THE PROPOSED LAKE ARTHUR DETENTION BASIN EXPANSION, CITY OF PORT ARTHUR, JEFFERSON COUNTY, TEXAS
}

\author{
Terracon Project No. 92197231
}

November 21, 2019

\subsection{INTRODUCTION AND MANAGEMENT SUMMARY}

On behalf of the City of Port Arthur (Client), archeologists from Terracon Consultants, Inc. (Terracon) conducted pedestrian survey of the 54-acre project area in Port Arthur, Jefferson County, Texas (Figures 1 and 2). This investigation assisted the Client in complying with requirements resulting from Federal Emergency Management Agency (FEMA) involvement under the National Environmental Policy Act (NEPA; Title 44, Part 10 CFR) and the Antiquities Code of Texas (Texas Natural Resources Code, Chapter 191, and Texas Administrative Code, Title 13, Chapter 26), and Section 106 of the National Historic Preservation Act (NHPA), (54 USC $\S$ 306101) and its implementing rules and regulations, 36 CFR 800. This project was conducted under Antiquities Permit \#9109.

The project area consists of a total area of 54 acres located on four separate parcels of land eastsoutheast of Lake Arthur Drive. The project area is divided into four parcels, two of which currently belong to the City of Port Arthur - Utility District (UD) and total slightly more than 35 acres, one of which currently belongs to H\&P Engineering \& Construction, Inc. and totals almost 14.5 acres, and one of which currently belongs to GTG Real Estate Holdings, LLC and totals approximately 4 acres (Figure 3). The City of Port Arthur has designated these subdivisions as "Area 1," "Area 2," and "Area 3". Investigation of the project area consisted of sampling by means of shovel testing. This resulted in the excavation of eleven (11) shovel tests. Fieldwork was conducted between October 15 and October 17, 2019 by Michael Hogan (Staff Archeologist) and Amani Bourji (Field Technician) under the supervision of Jenni Hatchett Kimbell (Principal Investigator). No cultural materials were identified during the survey. Large portions of the project area were inundated and thus inaccessible for survey. Based on Terracon's investigations, archeological sites considered eligible for inclusion in the National Register of Historic Places (NRHP) or warranting designation as State Antiquities Landmarks (SALs) are not known to be present within the project area. Additionally, in compliance with Section 106 of the NHPA, adjacent parcels were evaluated to determine whether historic properties might be present and subject to visual effects from the project. No such historic properties were identified.

Given the absence of intact archeological sites known to be present within the project area, Terracon recommends that the expansion of the Lake Arthur detention basin proceed as planned. In the event that human remains, historic properties, or other cultural materials are encountered during construction or disturbance activities, work should cease in the immediate area and Terracon, the Texas Historical Commission (THC) Archeology Division, or other proper authorities should be contacted. 
Cultural Resources Survey

Lake Arthur Detention Basin Expansion $\approx$ Port Arthur, Jefferson County, Texas

November 21, 2019 a Terracon Project No. 92197231

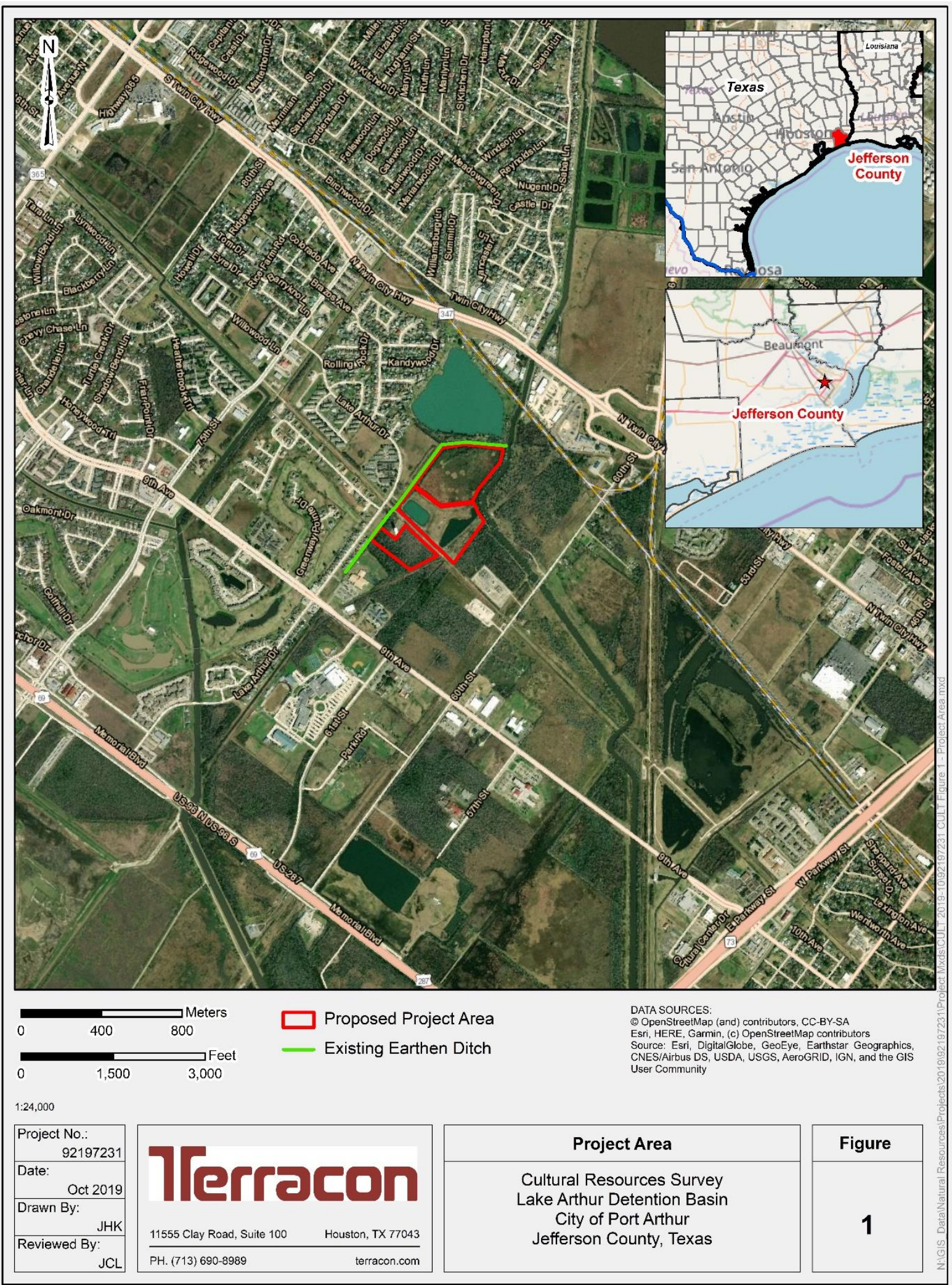

Figure 1. Project area. 


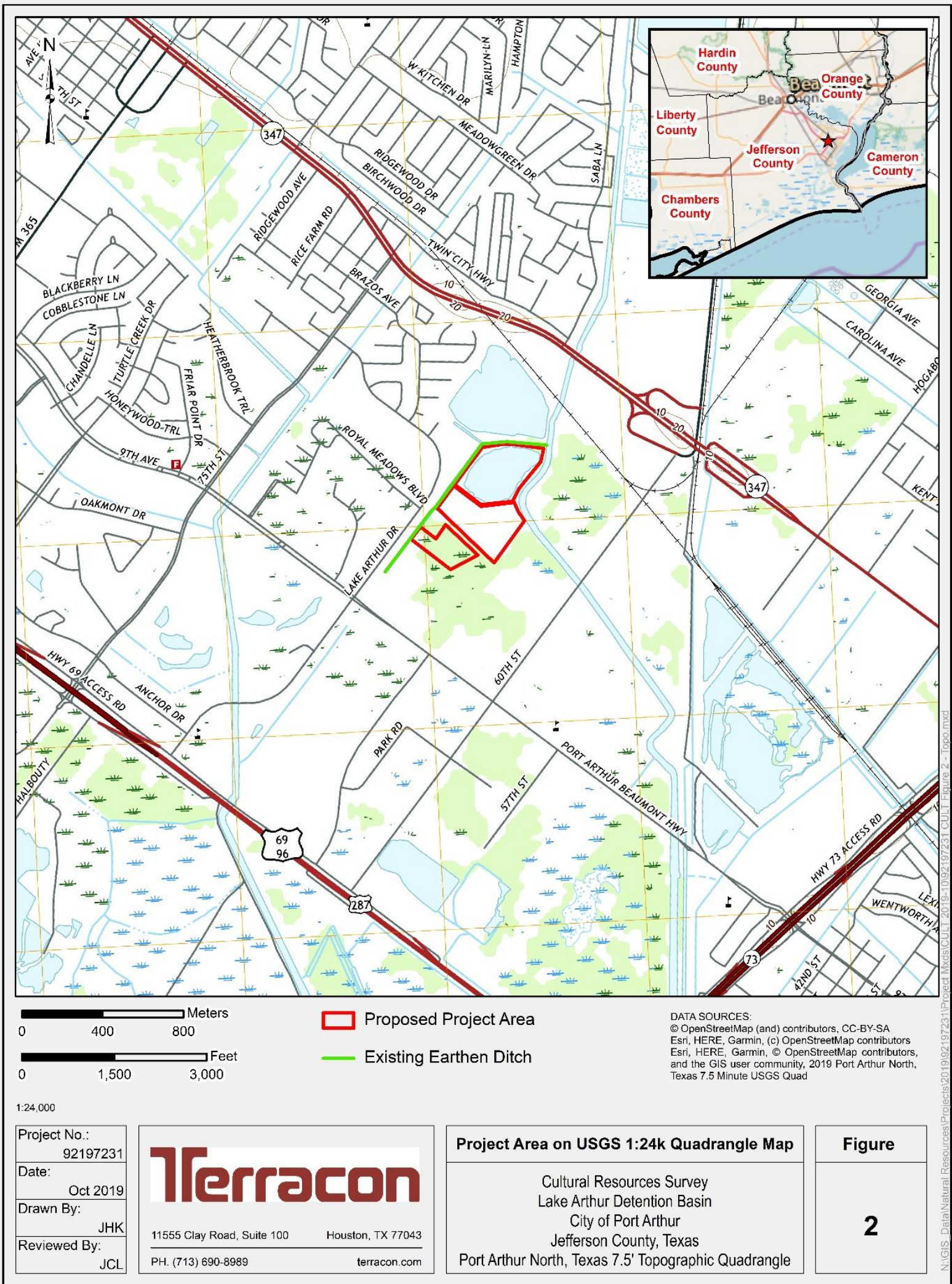

Figure 2. Project area on 2019 Port Arthur North USGS 7.5' quadrangle. 


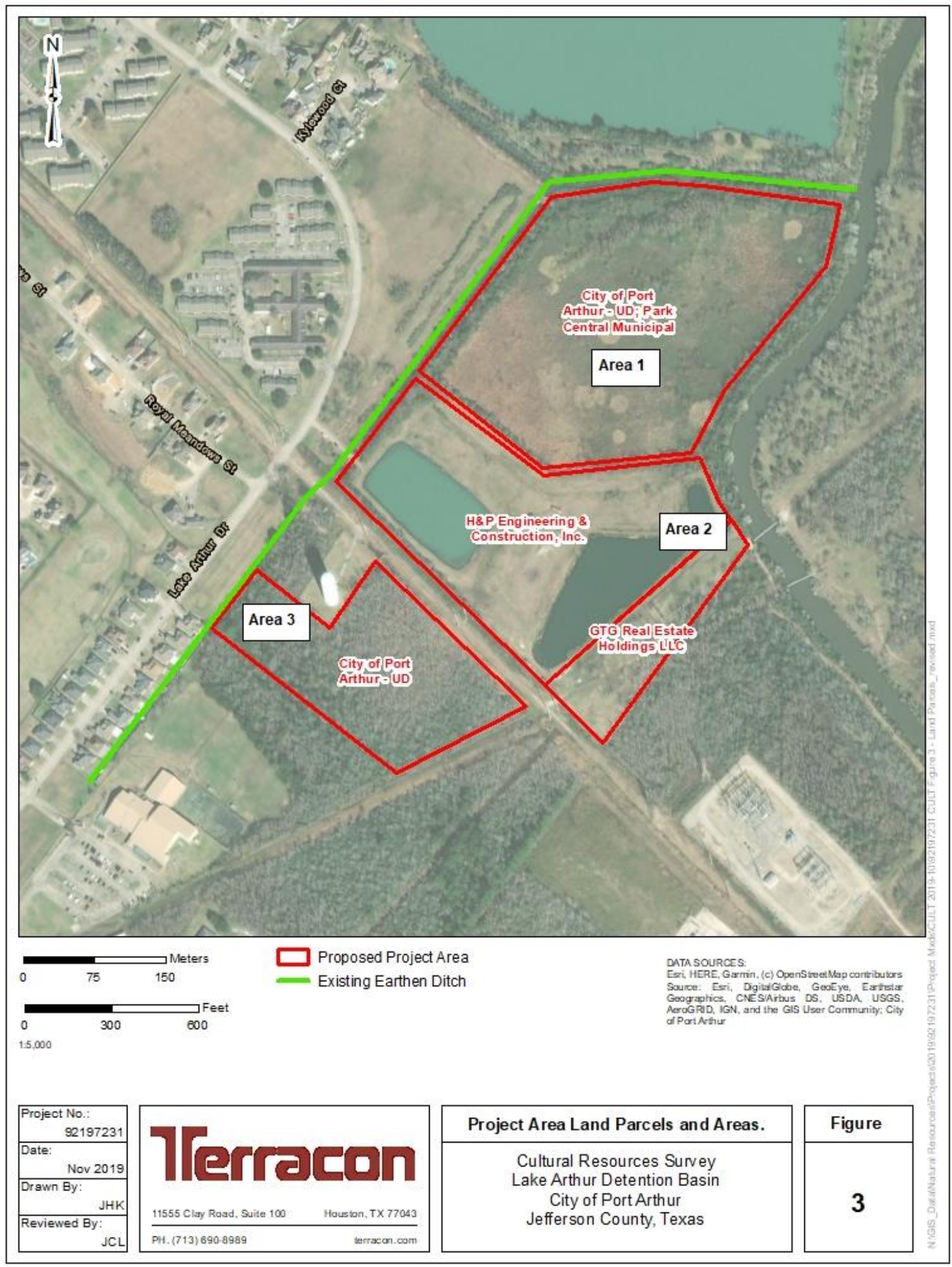

Figure 3. Project area land parcels and areas. 


\subsection{BACKGROUND}

\subsection{Environmental Setting}

The project area, located in Jefferson County, Texas, is in the Northern Humid Gulf Coastal Prairies of the Western Gulf Coastal Plain ecoregion, which is characterized by generally flat, low relief prairie landscapes dominated by coastal aeolian processes and slow-moving drainages that feed into the Gulf of Mexico (Griffith et al. 2007).

Jefferson County, like the rest of southeast Texas more broadly, is characterized by long, hot summers with short, moderate winters. Overall, the climate and physiography are dominated by Gulf moisture, which provides the source for most rainfall, including periodic hurricanes and other major tropic storms. Annual average precipitation is fifty-three inches (Kleiner 2019).

The local biotic community is dominated by marsh and prairie grasses and forested stands, consisting of some pine and mixed hardwoods, found mostly on elevated sandy ridges between waterways. Elevation of the surrounding area is approximately 20 feet above mean sea level.

\subsection{Culture History}

The project area is in what researchers call the Southeast Texas archeological region (Aten 1983; Patterson 1995; Story et al. 1990). Various syntheses have been presented for this area, but many of them suffer from the poorly stratified nature of prehistoric sites in the area and poor preservation conditions which cause organic remains to degrade, leaving few samples available for radiocarbon dating. As a result, regional chronologies tend to be imprecise and vague.

Following Aten (1983), regional prehistory is typically divided into three general periods: Paleoindian (12,000 BP to 9000 BP), Archaic (9000 BP to 3000 BP), and Late PrehistoricWoodland (3000 BP to $250 \mathrm{BP}$ ). Generally, these stages or periods are based on a series of economic transitions, including technology, subsistence, and settlement adaptations. To be sure, proposed shifts are related to climatic and environmental changes (Table 1), although these, like cultural transformations, are difficult to precisely date in the study area.

Table 1. Generalized culture history for Southeast Texas, with corresponding environmental periods.

\begin{tabular}{|c|c|c|}
\hline Time Period & $\begin{array}{c}\text { Years Before Present } \\
\text { (calibrated years cal BP) }\end{array}$ & Environmental Period \\
\hline Historic & 250 cal BP to $\sim$ AD 1950 & $\begin{array}{c}\text { Modern Era, sometimes referred } \\
\text { to as Anthropocene }\end{array}$ \\
\hline $\begin{array}{c}\text { Late Prehistoric- } \\
\text { Woodland }\end{array}$ & $3000-250$ cal BP & Early and Middle Holocene \\
\hline Archaic & $9000-3000$ cal BP & Terminal Pleistocene \\
\hline Paleoindian & $12,000-9000$ cal BP & \\
\hline
\end{tabular}


The Paleoindian period begins with the earliest evidence of human occupation in the study area, and in the New World. Archeologists have argued that during this time, human bands were highly nomadic, relied heavily on hunting strategies for food and other important resources, and maintained cultural territories covering large expanses of terrain. Exploitation of now extinct Pleistocene fauna (including bison, mammoth, mastodon, and other taxa) was common. Subsistence data, however, also show reliance on small game including rodents and turtles. This period, covering nearly 4,000 years, saw many important adaptations that led in short order to the definition and establishment of regional cultural traditions, reduced settlement mobility, and increased populations across the region. Diagnostic tool types for the early part of this period include Clovis and Folsom points, both of which are defined by sophisticated fluting techniques. Fluted points eventually gave way to other forms including San Patrice, Dalton, Scottsbluff, St. Mary's Hall, and others (Lohse 2013; Ricklis 2004).

By sometime around 10,200 years ago or more, Pleistocene climates underwent rapid warming; this marks the beginning of the Holocene and many of the so-called Archaic adaptations that followed. Megafauna became extinct, either from over-predation or climate change or both, and environmental habitats changed as rainfall regimes increased and sea levels rose in response to glacial melt. The predominating cultural patterns associated with this transition are the demonstrable increase in reliance on plant resources both for tools and for subsistence. Almost certainly, the perceived emphasis on plants is related in part to poor preservation of Pleistocene remains. Nevertheless, with the loss of most large-bodied prey species from the landscape, socially defined food-getting and economic strategies became refocused on smaller prey and a wider variety of caloric resources (Story et al. 1990). An important archeological indication of this shift is the appearance of plant cooking technology that used thermally heated rocks as a source of heat to transform carbohydrates into ingestible sugars (i.e., caloric energy) (Thoms 2009). This technique immediately made available several geophytes, root-based plant resources, as reliable sources of food. Throughout the Archaic, regional populations increased, albeit slightly, and some indications suggest increased interaction with other, distant regions. Southeast Texas never appears to have been directly linked into thriving or well-defined cultural patterns that covered large areas. Yet regional adaptations remained persistent and constant. One exception involves the Calf Creek interval, dated to about 5950-5700 cal BP. This brief period is defined by a sudden and intensive focus on bison hunting and followed a long period during which bison were absent from the study area. Calf Creek remains are found from western Louisiana across Texas and as far north on the Southern Great Plains as Kansas, eastern Colorado, Missouri, and western Arkansas (Thurmond and Wyckoff 1999).

The end of the Archaic in Southeast Texas corresponds with what Story et al. (1990) have termed the Mossy Grove archeological culture. In neighboring regions to the east, this period is called Woodland; each is defined by the appearance of pottery (first Tchefuncte then Goose Creek), but Woodland sites also commonly have domesticated plants, which appear to be absent from Mossy Grove assemblages. In terms of chipped stone tools, Gary points are ubiquitous across the region, and appear to last for an extended period. It seems likely that subtle variations within Gary point manufacturing and morphology might be discernable at sites where stratigraphic separation 
allows for such changes to be recognized. Following Costa et al. (2018), the last approximately 2,000 years of Southeast Texas prehistory might be best understood through a tripartite Mossy Grove sequence that reflect ceramic, lithic, and social developments. Under this recent scheme, Early Mossy Grove (EMG) begins with the appearance of pottery, probably diffusing westward from the Lower Mississippi Valley. This process extends until the appearance of the bow and arrow, perhaps around 1,200 years ago; this marks the beginning of so-called Middle Mossy Grove (MMG). This also marks the beginning of what is more commonly referred to as the Late Prehistoric period. Late Mossy Grove (LMG) reflects the eastern spread of a Plains-based economic system focused on the exploitation of bison, which appeared again in the study area for perhaps the first time since Calf Creek times.

Beginning in the early 1500s, European expeditions and incursions into Southeast Texas become increasingly frequent, including competition between the French and Spanish. As these foreign powers competed for influence in the region, they encountered Native groups including the Atakapa, Akokisa, Bidai, Karankawa, Tonkawa, and others who had been in the area for centuries or longer (Aten 1983). The region was a center for smuggling efforts until Mexico gained its independence from Spain, in 1821, and it began authorizing Anglo settlement into its northern territory of Tejas y Coahuila (Kleiner 2019). Beaumont was the first major settlement in the area, founded at Tevis Bluff in 1824. The economic prosperity of Antebellum Texas was reliant upon slavery; however, Jefferson County was less dependent on slave labor than certain other Texas counties, particularly of Brazoria, Wharton, Fort Bend, and parts of Harris County (Brown 1994). The 1860 United States census counted 1,995 persons in Jefferson County that year; 309 were slaves and 1,686 were white (Kleiner 2019). A small number of military actions occurred between Confederate troops and Union soldiers during the Civil War in Jefferson County, they were primarily concentrated around Sabine Pass and Sabine City including the battle of Sabine Pass in 1863. The economy of the Reconstruction Era in Jefferson County focused on agriculture and lumber, but the petrochemical industry expanded rapidly after the discovery of oil at Spindletop in 1901 (Kleiner 2019).

Port Arthur was founded in 1895 by Arthur E Stilwell, and construction of a canal to Sabine Pass was completed in 1899 (Storey 2019). In 1897 the city had a population of 860 but grew rapidly after the Spindletop oil discovery. By 1910 Port Arthur had 7,663 residents and in 1930 it had a population of 50,902 (Storey 2019).

\subsection{RESEARCH AND SURVEY METHODS}

A combination of desktop review and archeological fieldwork was employed to identify cultural resources present within both the project area and a half-mile study area. Desktop review focused on identifying previously known historic properties and archeological sites, while pedestrian survey was used to help determine if previously unknown archeological resources exist within the project area. 


\subsection{Desktop Review}

The desktop review was conducted by consulting United States Department of Agriculture (USDA) Natural Resources Conservation Service (NRCS) soils data; the Texas Historical Commission's online database, the Texas Archeological Sites Atlas (Atlas), which is restricted to qualified archeologists; historical-period USGS topographic maps and other historical maps; the National Register of Historic Places (NRHP) website; the Texas Freedom Colonies Atlas; TxDOT electronic resources for historical-period sites and bridges; and historical aerial photographs. These sources provide information on factors that affect the likelihood of intact archeological deposits being present, previous archeological investigations, known prehistoric or historicalperiod sites, and historic properties listed in or eligible for listing in the NRHP within a half-mile radius of the project area. It should be noted that, while Atlas includes spatial data representing many of the archeological investigations conducted over the last five decades or so in Texas, this aspect of Atlas is lacking much information. Additionally, the information available varies widely in quality, detail, and accuracy; this is particularly true for investigations conducted more than 20 years ago.

\subsection{Cultural Resources Survey}

Terracon archeologists investigated the project area by means of a systematic survey and shovel tests to identify and delineate cultural resources. The investigation was conducted in accordance with standards proposed by the Council of Texas Archeologists (CTA) and accepted by the THC. According to current CTA standards, project areas of this size (54 acres) should be evaluated with a shovel test density of one probe for every two (2) acres. Of the 54 acres within the project area, approximately 32 acres were inundated, leaving only 22 acres accessible for survey. Shovel tests were not completed in a small portion of the project area due to the presence of a pipeline right-of-way. The pedestrian survey was conducted in approximate 100-meter intervals along transects spaced approximately 100 meters apart across accessible portions of the project area, in order to properly assess the project area. Due to significant inundation, 11 shovel tests were excavated. Shovel tests were evenly spaced across the project area, measured approximately 30 $\mathrm{cm}$ in diameter, and were excavated in $20-\mathrm{cm}$ arbitrary levels to sediments inferred to predate human occupation in the area. Sediments removed from each shovel test were passed through $1 / 4$-inch hardware mesh to screen for artifacts and identified using Munsell® Soil-Color Charts. Shovel test data was recorded using shovel test logs. The locations of shovel tests were recorded with a handheld Trimble Global Positioning System (GPS) device with sub-meter accuracy. A photograph of the surrounding environment was taken at every shovel test using a digital camera and photo logs were maintained throughout the project. 


\subsection{RESULTS}

\subsection{Desktop Review}

The majority of the project area is located within an area mapped as League clay (LeaA), 0 to 1 percent slopes (Figure 4). These soils are characterized as somewhat poorly drained, very slowly permeable soils that formed in clayey fluviomarine deposits derived from the Beaumont Formation (NRCS 2019).

Terracon accessed the Texas Archeological Sites Atlas on June 28, 2019 and assessed the project area and the area within a one-half-mile radius of the project area for the presence of previous archeological investigations and previously recorded archeological sites, including sites listed in or eligible for listing in the NRHP, as well as cemeteries and significant historic sites (THC 2019). Atlas revealed no archeological sites, cemeteries, or NRHP-listed or eligible properties within a one-half-mile radius of the project area (Figure 5). A single archeological investigation was conducted within the half mile radius of the project area in 1975 for the Texas Department of Highways and Public Transportation, but no sites were recorded near the project area. However, the lack of recorded archeological sites may be more reflective of a lack of investigations rather than a true dearth of archeological deposits.

The Texas Freedom Colonies Project (TFCP) shows no known sites within or near the project area, although several colonies are documented within Jefferson, Harris, and Montgomery Counties (TFCP 2019). Neither TxDOT's NRHP Listed and Eligible Bridges of Texas (2019a) database or their Historic Districts and Properties of Texas (2019b) database showed historic properties in or around the project area.

The project area is mapped on the Port Arthur North USGS topographic quadrangle map. For purposes of identifying potential historical-period structures, the 1:24,000 USGS topographic quadrangle maps are ideal; for this area the oldest available USGS maps at that scale date to 1943 (USGS 2019). Port Arthur North USGS topographic maps were examined for available years (1943, 1957, 1970, 1975, 1993). Other USGS topographic maps available for this area include Port Arthur 1:250,000 (1954, 1956, 1958, 1973) and 1983 Port Arthur 1:100,000 maps (USGS 2019). No historical-period resources within or near the project area were identified on these maps; however, the dirt road/right-of-way that runs between Area 2 and project Area 3 was present as early as 1943 .

Google Earth ${ }^{\mathrm{TM}}$ imagery dating from 1938, 1989, and 1995 were reviewed and did not reveal historical-period structures within or adjacent to the project area. Aerial imagery shows the presence of the unnamed dirt road/right-of-way located between project areas the central and southernmost land parcels in 1938, the construction of the northwestern detention basin in the central land parcel in 2005, and the construction of the southeastern detention basin in the central land parcel between 2010 and 2011. 


\section{Tlerracon}

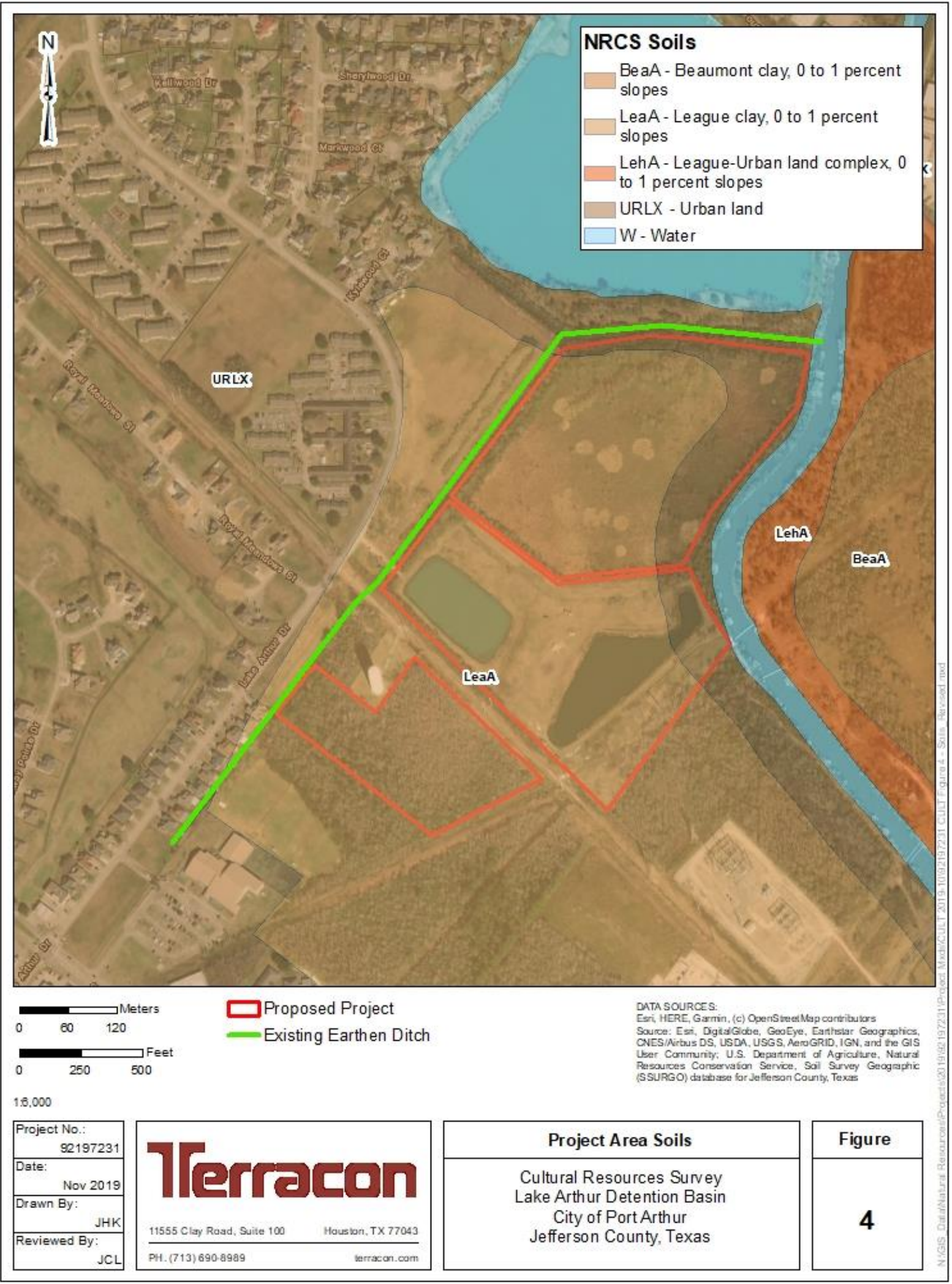

Figure 4. Project area soils. 
Cultural Resources Survey

Lake Arthur Detention Basin Expansion $\approx$ Port Arthur, Jefferson County, Texas

November 21, 2019 — Terracon Project No. 92197231

Figure Redacted for Site Protection

Figure 5. Results of the desktop assessment. 


\subsection{Cultural Resources Survey}

The project area is divided into four parcels, two of which currently belong to the City of Port Arthur - Utility District (UD) and total slightly more than 35 acres, one of which currently belongs to H\&P Engineering \& Construction, Inc. and totals almost 14.5 acres, and one of which currently belongs to GTG Real Estate Holdings, LLC and totals approximately 4 acres (Figure 6). The City of Port Arthur has designated these subdivisions as "Area 1," "Area 2," and "Area 3" as shown on Figure 5. The cultural resources survey consisted of the excavation of 11 shovel tests (Figures 7 and 8). No subsurface artifacts were recovered from the shovel tests, and no cultural resources were observed during the survey.

\section{Area 1: City of Port Arthur - Utility District; Park Central Municipal Parcel}

The northernmost land parcel is the City of Port Arthur - Utility District; Park Central Municipal parcel and makes up the entirety of Area 1 on Figure 6. Area 1 makes up approximately 40 percent of the project area and is characterized by an inundated area that is approximately one meter lower than the surrounding landform and is composed of two-meter-tall marsh grasses located in knee-high water (Figures 9 and 10). Surface visibility was very low in this area, near zero percent, and no shovel tests were excavated in this parcel due to high water. No cultural resources were observed within the visible areas.

\section{Area 2: GTG Real Estate Holdings, LLC Parcel}

The easternmost land parcel in Area 2 is the GTG Real Estate Holdings, LLC parcel. It makes up approximately 20 percent of Area 2, which covers approximately 40 percent of the overall project area (see Figure 6). The GTG Real Estate Holdings, LLC parcel consists of low, manicured grass with an oil pipeline right-of-way running from the northeast corner of the parcel to the southwest, taking up the majority of the parcel. Two shovel tests were excavated within this parcel. The AP horizon was shallow, possibly truncated due to the significant amount of disturbance in the area, and subsoils inferred to predate human occupation in the area were reached within the first 10 centimeters. No cultural resources were observed within this parcel.

\section{Area 2: H\&P Engineering \& Construction, Inc. Parcel}

The westernmost land parcel in Area 2 is the H\&P Engineering \& Construction, Inc. parcel (see Figure 6). It makes up the remaining 80 percent of Area 2, which covers approximately 40 percent of the overall project area. The parcel consists of low, manicured grass with man-made ponds (Figures 11 and 12). Six shovel tests were excavated within this parcel. The AP horizon was shallow, possibly truncated due to the significant amount of disturbance in the area, and subsoils inferred to predate human occupation in the area were reached within the first 10 centimeters. No cultural resources were observed within this parcel. 
Cultural Resources Survey

Lake Arthur Detention Basin Expansion $\approx$ Port Arthur, Jefferson County, Texas

November 21, 2019 — Terracon Project No. 92197231

Figure Redacted for Site Protection

Figure 6. Results of the pedestrian survey. 


\section{Cultural Resources Survey}

Lake Arthur Detention Basin Expansion $\approx$ Port Arthur, Jefferson County, Texas November 21, 2019 a Terracon Project No. 92197231

\section{Terracon}

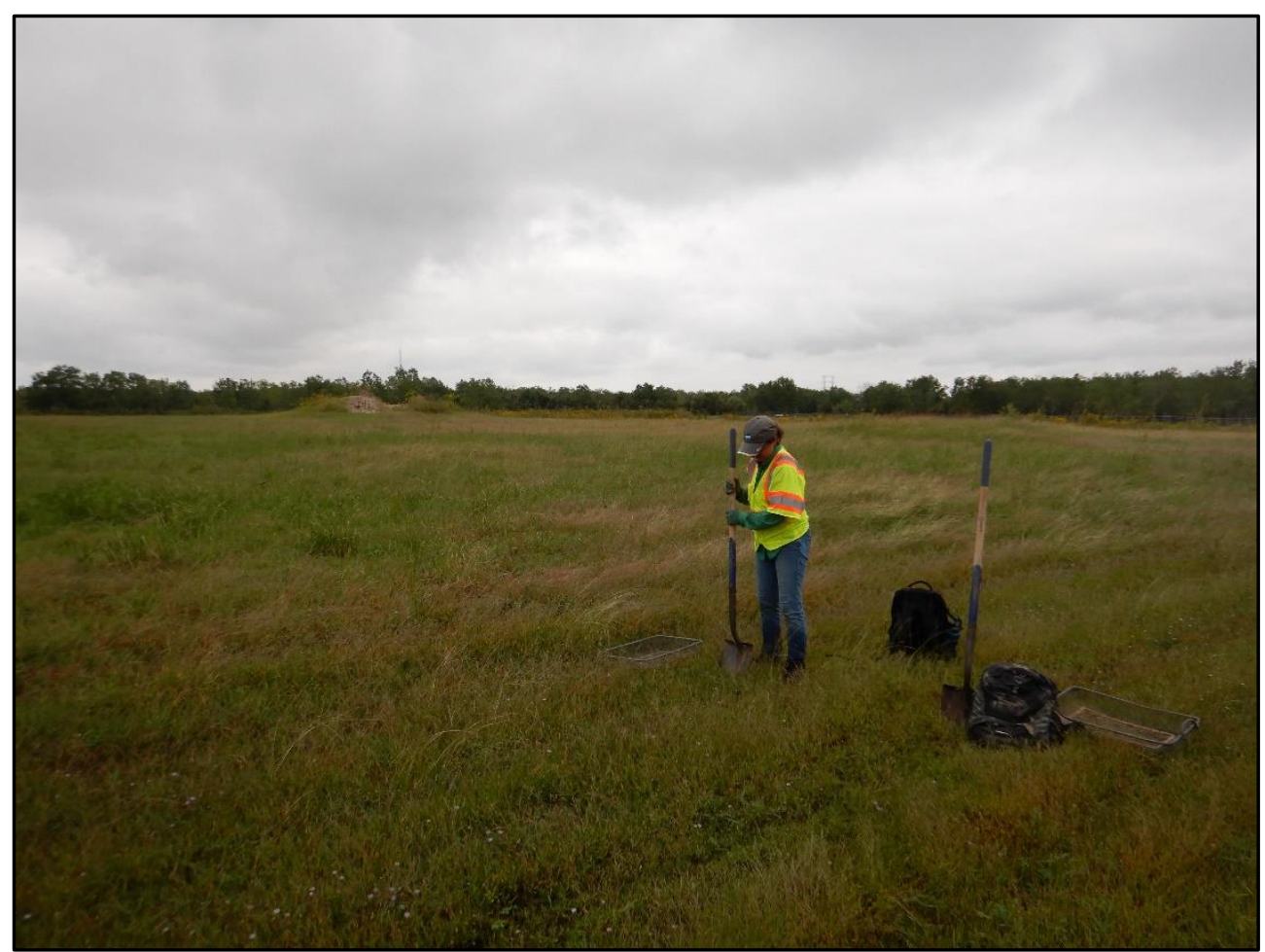

Figure 7. Excavation of shovel test IP10 in Area 2 (facing northeast).

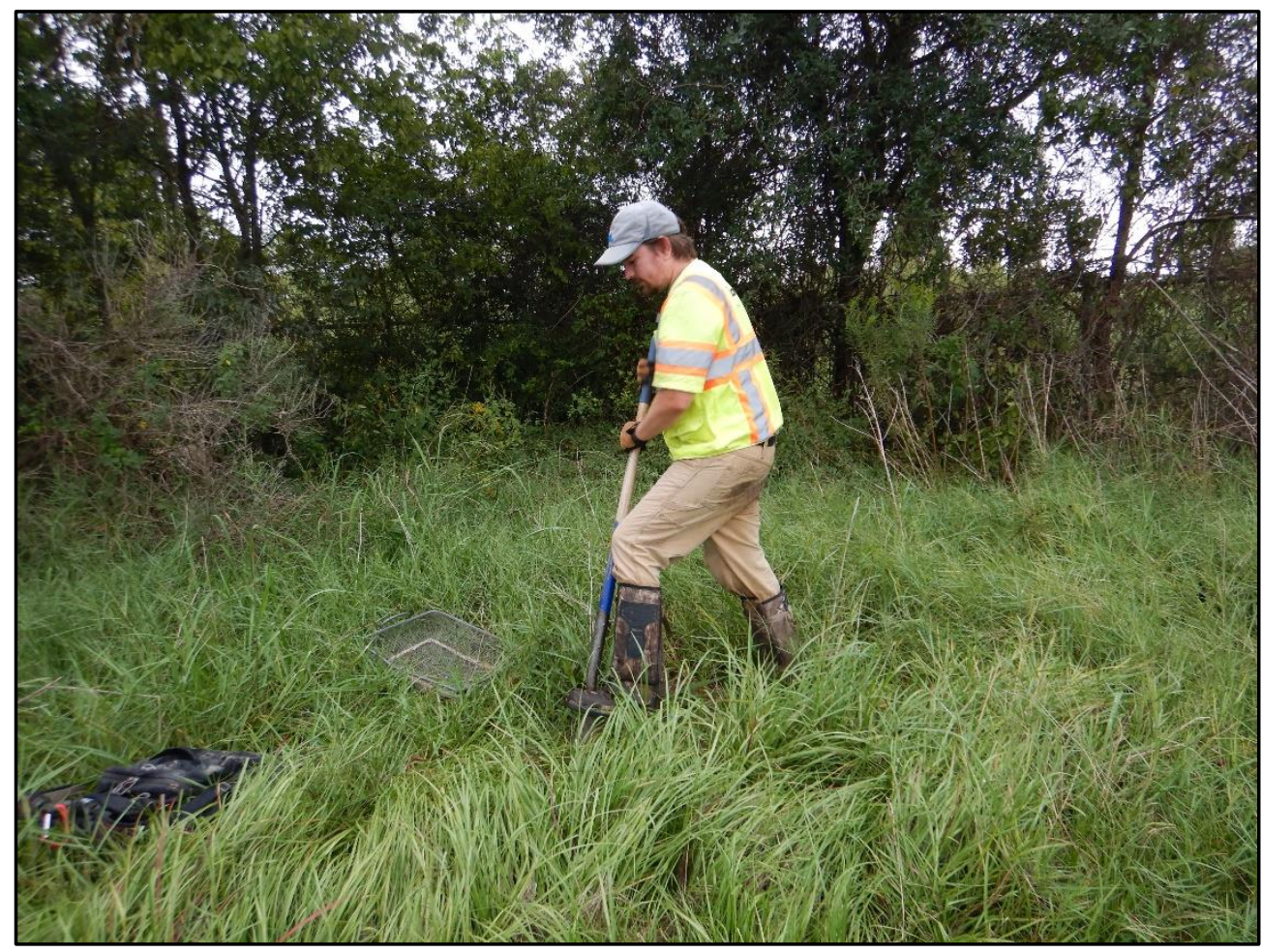

Figure 8. Excavation of shovel test IP12 in Area 2 (facing west). 


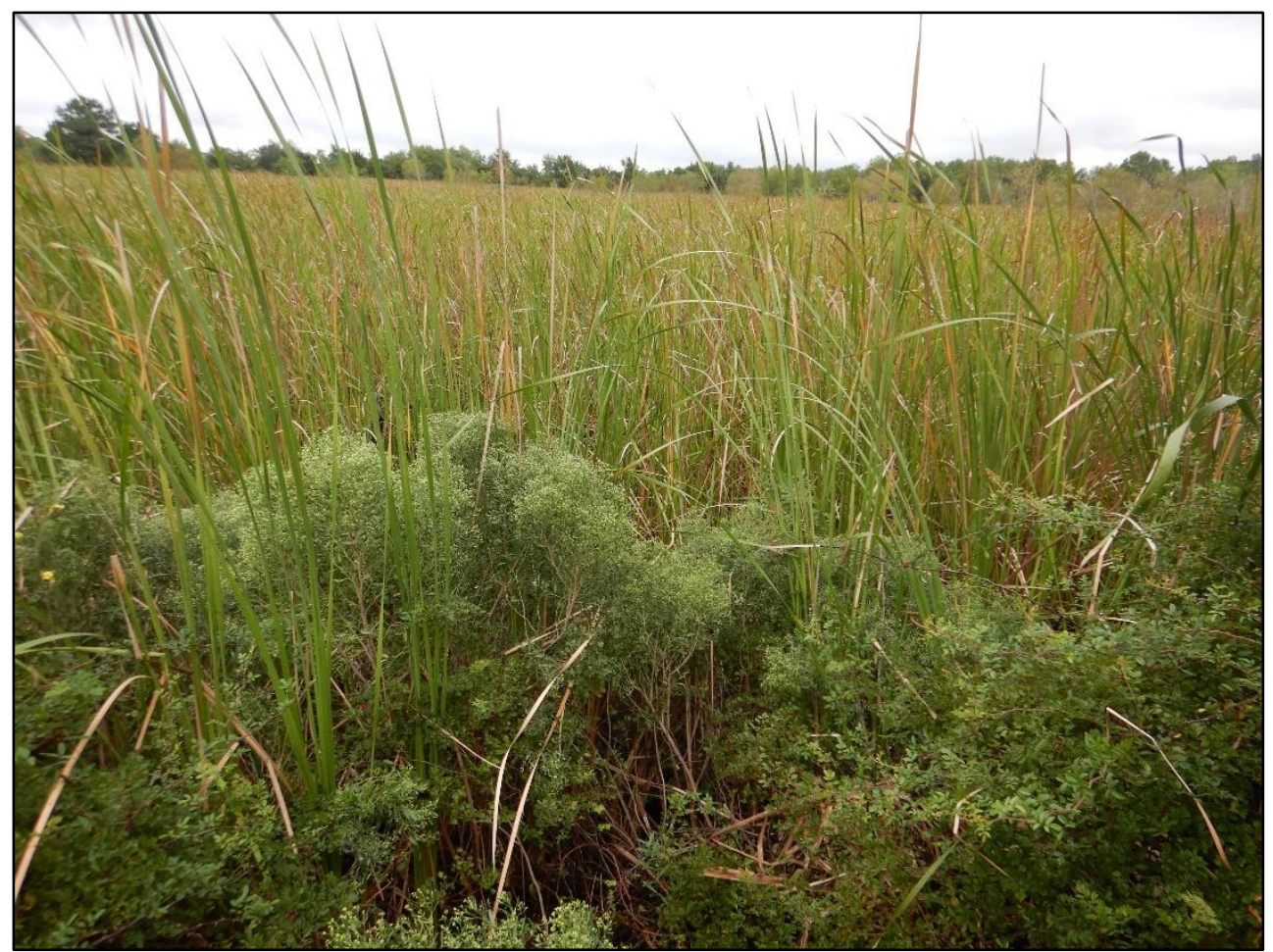

Figure 9. Vegetation in the northernmost land parcel, Area 1 (facing northwest).

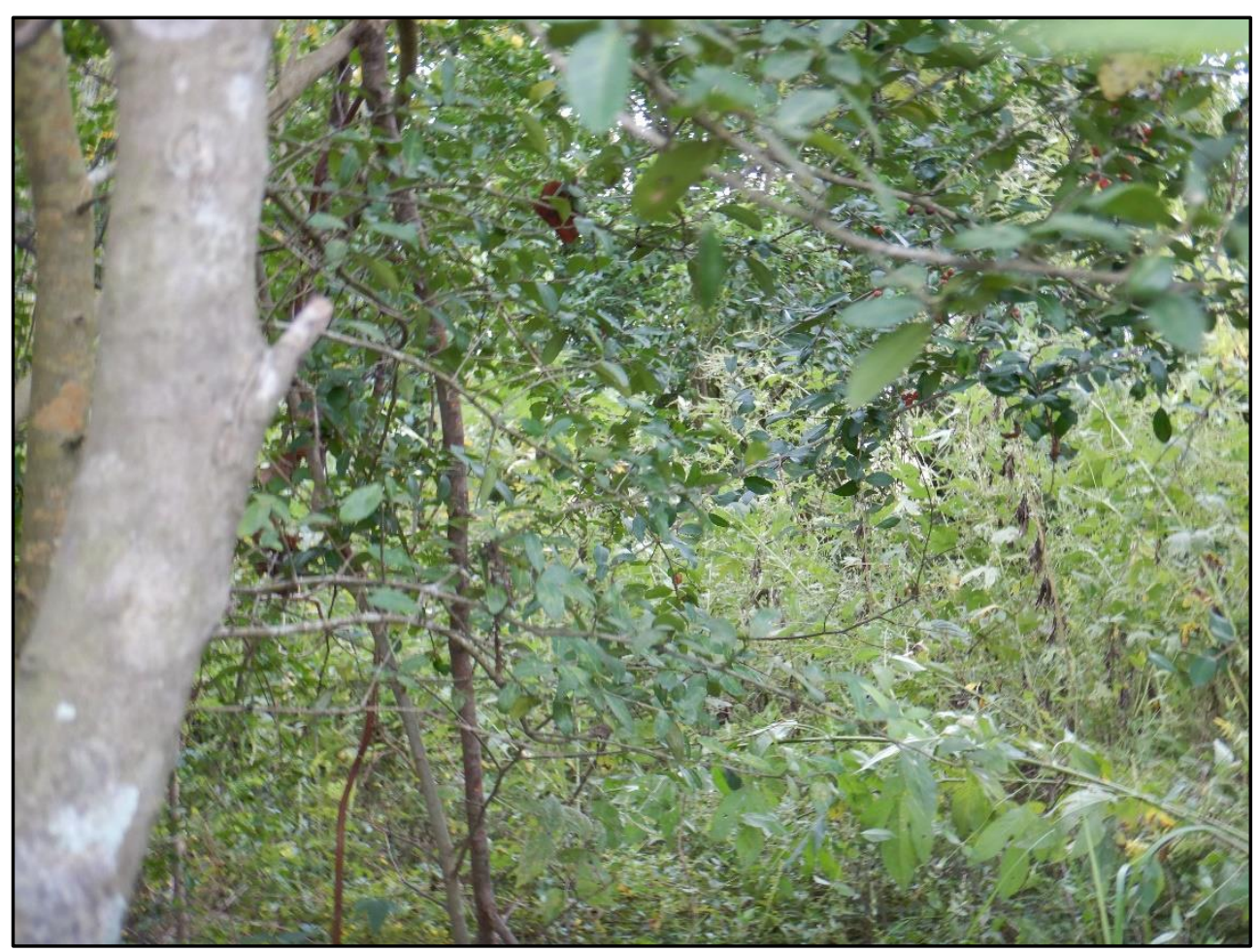

Figure 10. Vegetation in the northernmost land parcel, Area 1 (facing southwest). 


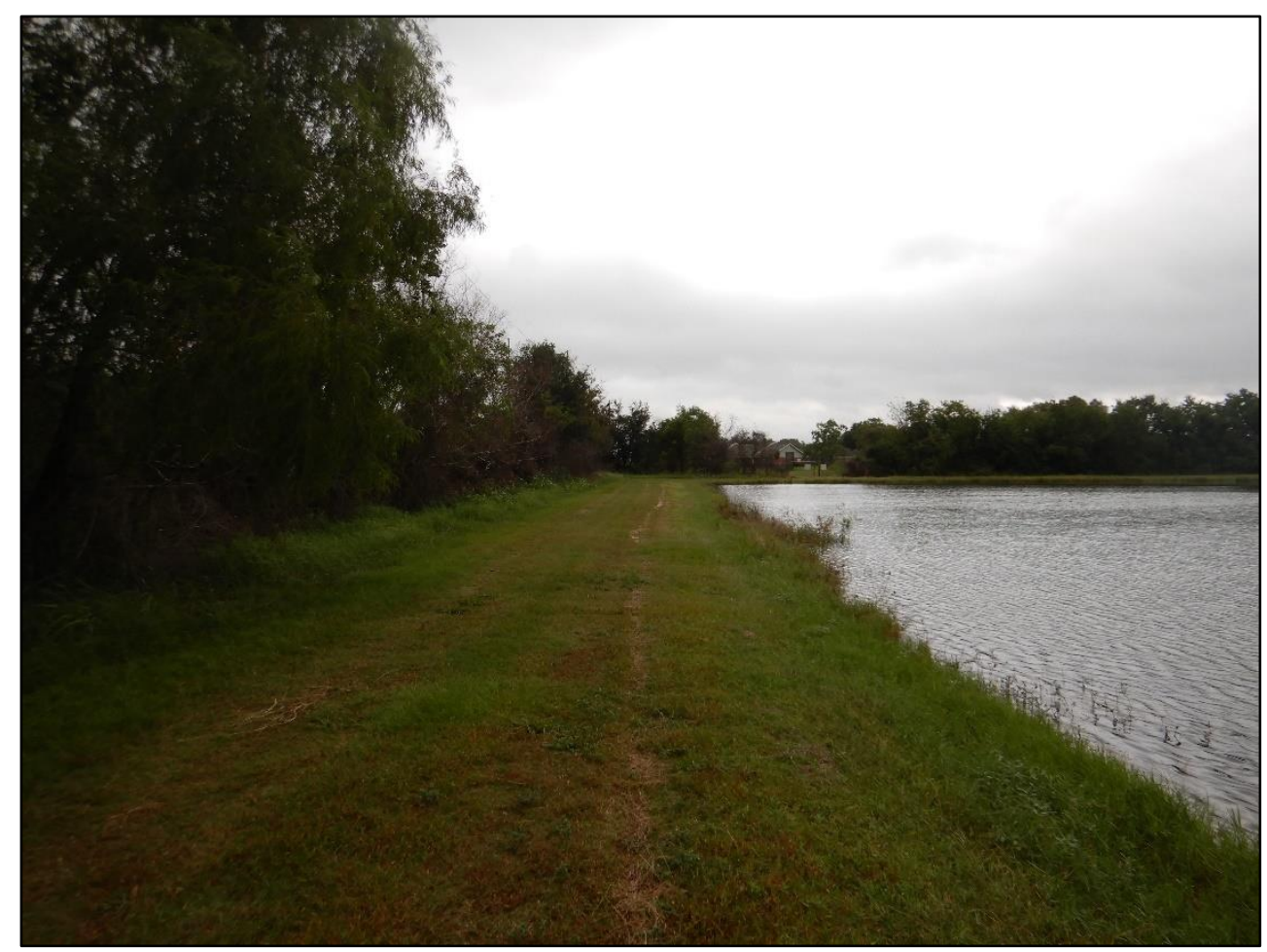

Figure 11. Vegetation in the central land parcels, Area 2 (facing west).

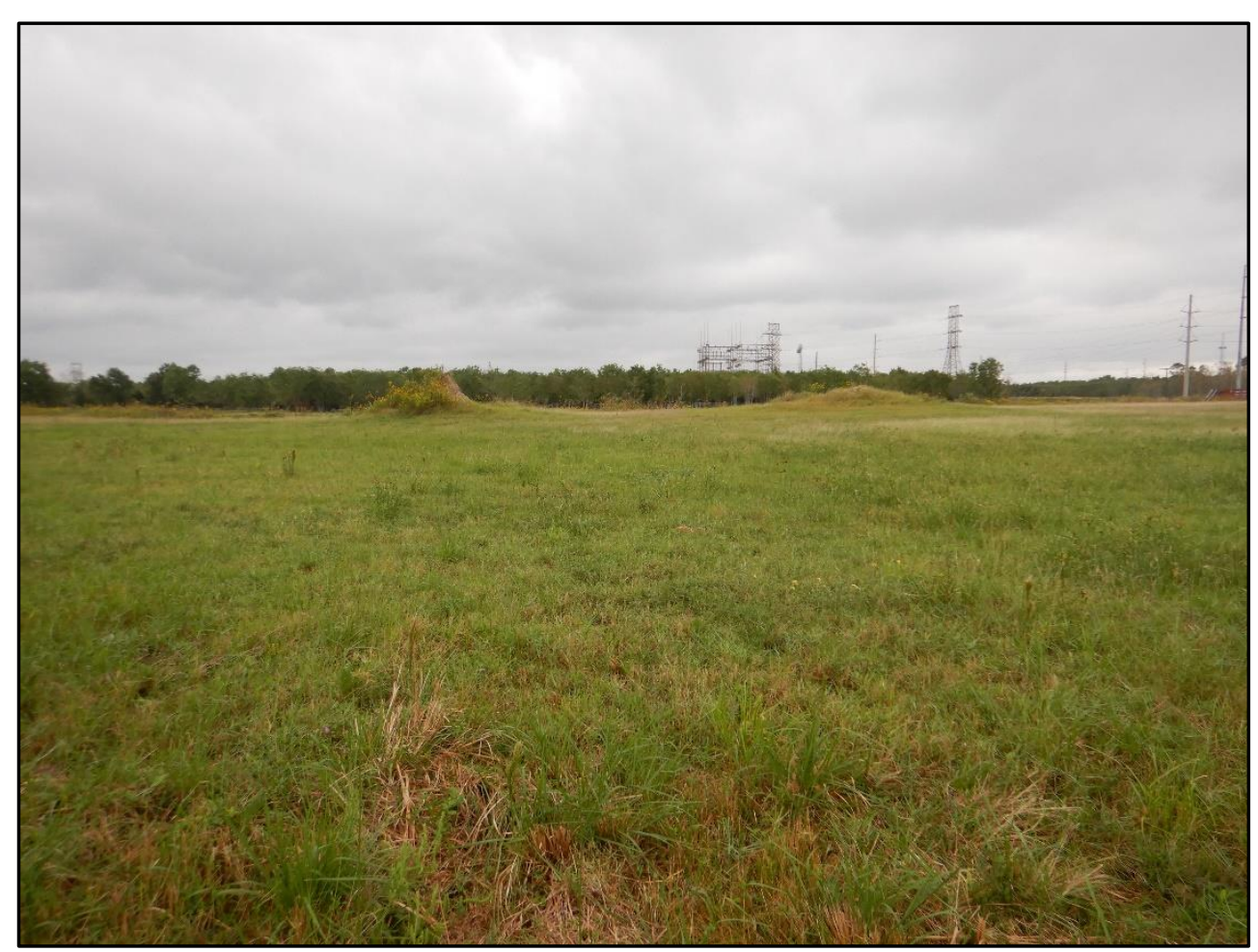

Figure 12. Vegetation in the central land parcels, Area 2 (facing east). 


\section{Area 3: City of Port Arthur - Utility District Parcel}

The southernmost land parcel makes up the entirety of Area 3 and is the City of Port Arthur Utility District parcel (see Figure 6). It makes up the remaining 20 percent of the overall project area. The parcel consisted of thick woods with ankle deep water (Figures 13 and 14). Three shovel tests were excavated within this parcel. The AP horizon was shallow, possibly truncated due to the significant amount of disturbance in the area, and subsoils inferred to predate human occupation in the area, or the water table, were reached within the first 10 centimeters. No cultural resources were observed within this parcel.

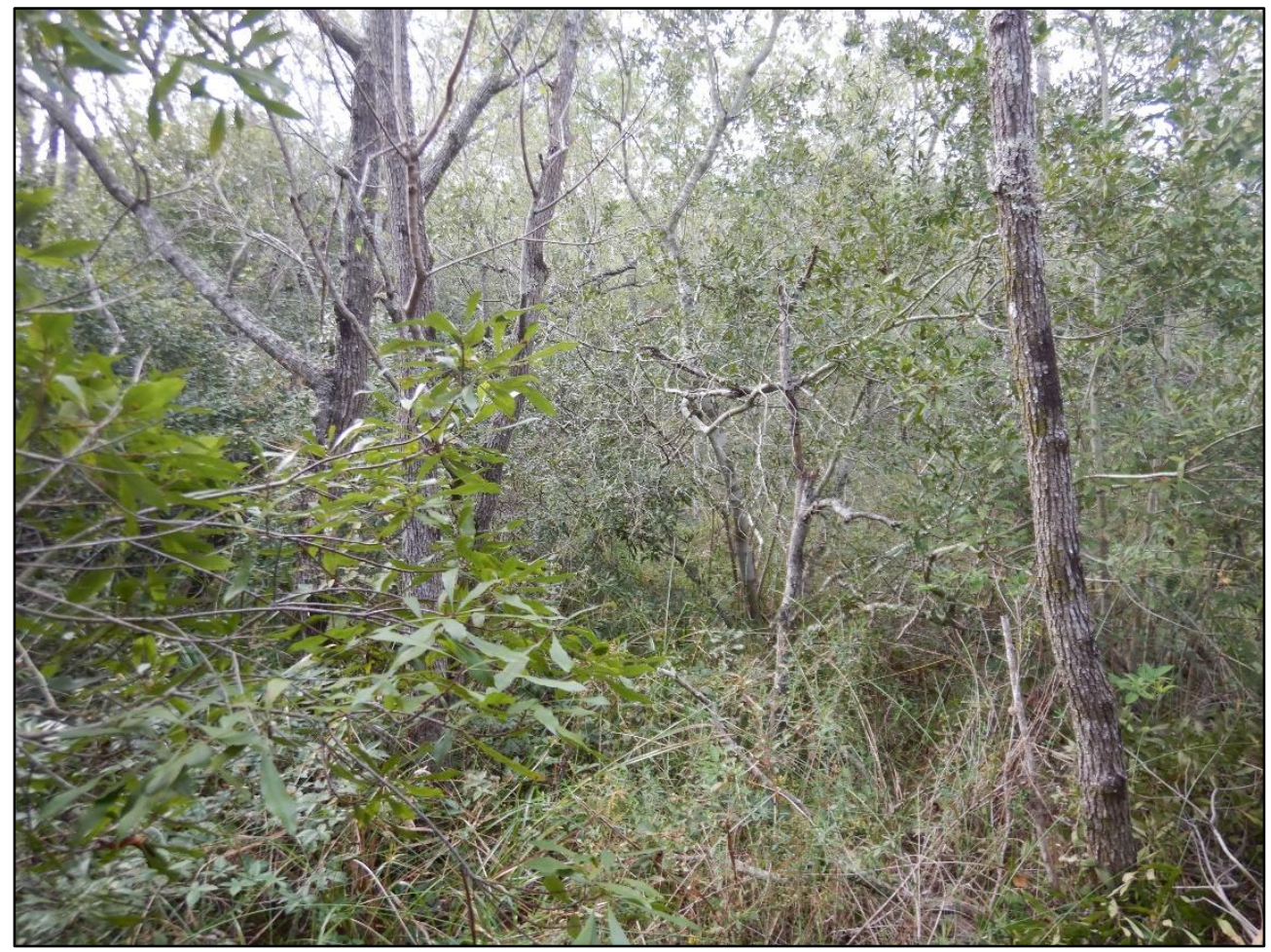

Figure 13. Vegetation in the southern land parcel, Area 3 (facing south). 


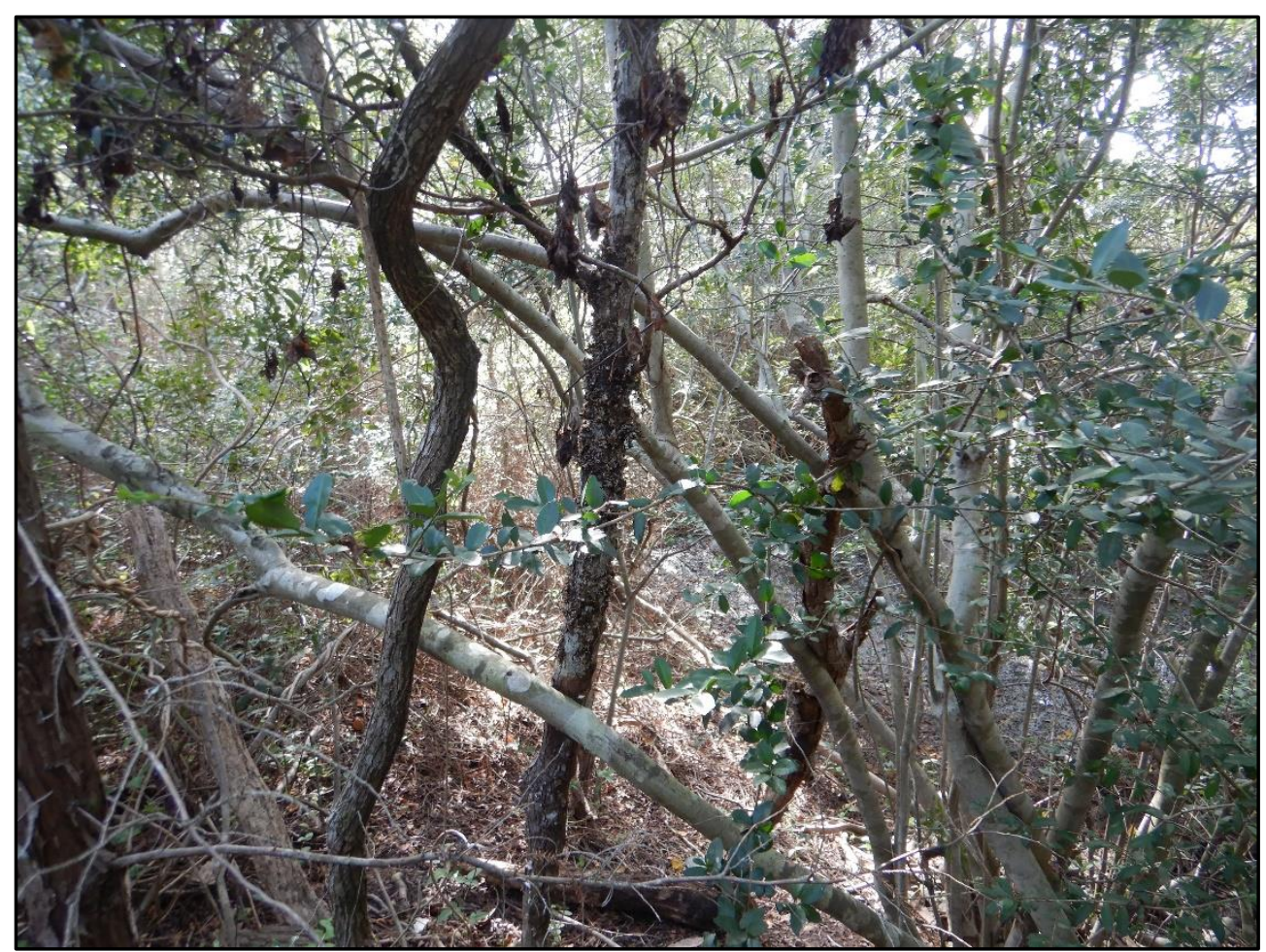

Figure 14. Vegetation in the southern land parcel, Area 3 (facing west).

\subsection{CONCLUSIONS AND RECOMMENDATIONS}

Terracon archeologists conducted a desktop review for known cultural resources and a cultural resources survey of an approximately 54-acre project area in and for the City of Port Arthur, Jefferson County, Texas. The project area was sampled through the excavation of 11 shovel tests. No cultural materials were identified during the survey. Additionally, in compliance with Section 106 of the NHPA, adjacent parcels were evaluated to determine whether historic properties might be present and subject to visual effects from the project. No such historic properties were identified.

Based on the results of the current investigation, it is Terracon's assessment that no known historic properties or cultural resources eligible for inclusion in the NRHP will be affected by the proposed project. Therefore, Terracon recommends that the expansion of the Lake Arthur detention basin proceed as planned. In the unlikely event that human remains, historic properties, or buried cultural materials are encountered during construction or disturbance activities, work should cease in the immediate area and Terracon, the THC's Archeology Division, or other proper authorities should be contacted. 


\section{REFERENCES CITED}

Aten, Lawrence $\mathrm{E}$.

1983 Indians of the Upper Texas Coast. Academic Press, New York.

Brown, Kenneth L.

1994 Material Culture and Community Structure: The Slave and Tenant Community at Levi Jordan's Plantation, 1848-1892. In Working Toward Freedom: Slave Society and Domestic Economy in the American South, edited by Larry E. Hudson, Jr., pp. 95-118. University of Rochester Press, New York.

Costa, August G., Anastasia Gilmer, and Eleanor Stoddart

2018 Cultural Background. In Excavations at the Luce Bayou Site (41LB42): A Mossy Grove Ridgeline Site in the Lower Trinity River Valley, Southeast Texas, edited by August G. Costa and Anastasia Gilmer, pp. 20-33. Report of Investigations Number 658, Moore Archeological Consulting, Inc., Houston.

Griffith, G.E., S.A. Bryce, J.M. Omernik, J.A. Comstock, A.C. Rogers, B. Harrison, S.L. Hatch, and D. Benzason

2007 Ecoregions of Texas. U.S. Environmental Protection Agency, Corvallis.

Kleiner, Diana J.

2019 Jefferson County. Handbook of Texas Online. Electronic resource, https://tshaonline.org/handbook/online/articles/hcj05, accessed June 28, 2019.

Lohse, Jon C., editor

2013 Underwater Archeology at 41HY147, the Terrace Locality at Spring Lake. Archeological Studies Report No. 28. Center for Archeological Studies, Texas State University-San Marcos.

Natural Resources Conservation Service (NRCS), USDA, Soil Survey Staff

2019 Web Soil Survey. Electronic resource, http://websoilsurvey.nrcs.usda.gov/, accessed October 21, 2019.

Patterson, Leland W.

1995 The Archeology of Southeast Texas. Bulletin of the Texas Archeological Society 66:239264.

Ricklis, Robert A.

2004 The Archeology and Native American Occupation of Southeast Texas. In The Prehistory of Texas, edited by Timothy K. Perttula, pp. 181-202. Texas A\&M University Press, College Station.

Storey, John W.

2019 Port Arthur, TX. Handbook of Texas Online. Electronic resource, https://tshaonline.org/handbook/online/articles/hdp05, accessed June 28, 2019. 
Story, Dee Ann, Janice A. Guy, Barbara A. Burnett, Martha D. Freeman, Jerome C. Rose, D. Gentry Steele, Ben W. Olive, and Karl J. Reinhard

1990 The Archeology and Bioarcheology of the Gulf Coastal Plain: Volume 1. Arkansas Archeological Survey Research Series No. 38, Fayetteville.

Texas Department of Transportation (TxDOT)

2019a NRHP Listed and Eligible Bridges of Texas. Electronic resource, https://txdot.maps.arcgis.com/apps/webappviewer/index.html?id=cc9cf3452a324d0bb96 1a0c8b4edd898, accessed October 21, 2019.

2019b Historic Districts and Properties of Texas. Electronic resource, https://txdot.maps.arcgis.com/apps/webappviewer/index.html?id=077104987672487b9b 320cc424d588a2, accessed October 21, 2019.

Texas Freedom Colonies Atlas (TFCP)

2019 Texas Freedoms Colonies Atlas. Electronic resource, http://www.thetexasfreedomcoloniesproject.com, accessed July 1, 2019.

Texas Historical Commission (THC)

2019 Texas Archeological Site Atlas. Electronic resource, https://atlas.thc.state.tx.us/, accessed July 1, 2019.

Thoms, Alston V.

2009 Rocks of Ages: Propagation of Hot-Rock Cookery in Western North America. Journal of Archeological Science 36:573-591.

Thurmond, J. Peter, and Don G. Wyckoff

1999 The Calf Creek Horizon in Northwestern Oklahoma. Plains Anthropologist 44:231-250.

United States Geological Survey (USGS)

2019 Historical Topographic Map Explorer. Electronic resource, http://historicalmaps.arcgis.com/usgs/, accessed October 21, 2019. 


\section{Appendix Investigation Point Log}




\begin{tabular}{|c|c|c|c|c|c|c|c|c|}
\hline IP\# & $\begin{array}{c}\text { ST \#/ SST } \\
\#\end{array}$ & $+/-$ & $\begin{array}{l}\text { Depth } \\
\text { (cmbs) }\end{array}$ & Munsell \& Color & Soil Texture & $\begin{array}{l}\text { Surface } \\
\text { Visibility }\end{array}$ & Setting Description & Shovel Test Comments \\
\hline 1 & ASB01 & - & $0-20$ & $\begin{array}{l}\text { 10YR5/1 Gray } \\
\text { mottled with } \\
\text { 10YR4/2 Dark } \\
\text { Grayish Brown }\end{array}$ & $\begin{array}{l}\text { Clay Loam, } \\
\text { Very } \\
\text { Saturated }\end{array}$ & $0 \%$ & $\begin{array}{l}\text { Mixed hardwoods and tall } \\
\text { wetland plants. }\end{array}$ & $\begin{array}{l}\text { No cultural materials. Over } 5 \% \text { fe } \\
\text { oxidation in soil. Large number of } \\
\text { small roots. Mottling less than } 7 \% \text {. } \\
\text { Inundated soil. Terminated at } 20 \\
\text { cm due to water table }\end{array}$ \\
\hline 2 & MNH01 & - & $0-20$ & $\begin{array}{l}\text { 10YR4/1 Dark Gray, } \\
\text { heavily mottled }\end{array}$ & $\begin{array}{l}\text { Loamy Clay, } \\
\text { Inundated }\end{array}$ & $10 \%$ & $\begin{array}{l}\text { Dense wooded area. Standing } \\
\text { water }\end{array}$ & $\begin{array}{l}\text { Inundated. No gravels. Roots } \\
\text { throughout. No cultural materials. } \\
\text { Terminated due to clay }\end{array}$ \\
\hline 3 & No Dig & - & & & & $0 \%$ & $\begin{array}{c}\text { Offset point due to inundation } \\
\text { within area with tall wetland } \\
\text { plants }\end{array}$ & Inundated area. \\
\hline 4 & $\mathrm{MNHO2}$ & - & $0-40$ & 10YR3/1 Dark Gray & $\begin{array}{l}\text { Clay, Heavy } \\
\text { Mottling, Dry }\end{array}$ & $0 \%$ & $\begin{array}{l}\text { Located on side of creek Just } \\
\text { South of thick wooded area }\end{array}$ & $\begin{array}{l}\text { Very compact. No gravels. Roots } \\
\text { throughout. No cultural materials. }\end{array}$ \\
\hline 5 & No Dig & - & & & & $0 \%$ & $\begin{array}{c}\text { Offset point due to inundation } \\
\text { within area with tall wetland } \\
\text { plants }\end{array}$ & $\begin{array}{l}\text { Inundated area and impassible } \\
\text { terrain }\end{array}$ \\
\hline 6 & No Dig & - & & & & $0 \%$ & $\begin{array}{c}\text { Located along pipeline ROW. } \\
\text { Manicured grass }\end{array}$ & No dig. Oil pipeline \\
\hline 7 & ASB02 & - & $0-30$ & $\begin{array}{c}\text { 10YR3/1 Very Dark } \\
\text { Gray mottled with } \\
\text { 10YR5/2 Grayish } \\
\text { Brown }\end{array}$ & $\begin{array}{l}\text { Clay Loam, } \\
\text { disturbed, } \\
\text { super } \\
\text { saturated }\end{array}$ & $10 \%$ & $\begin{array}{l}\text { Near fenceline; around } \\
\text { inundated area. }\end{array}$ & $\begin{array}{l}\text { No cultural materials. Over } 15 \% \\
\text { gravel and shells in last } 15 \mathrm{cmbs} \text {. } \\
\text { Over } 15 \% \text { CaCO3. Mottling over } \\
10 \% . \text { Fe oxidation over } 7 \% . \\
\text { Terminated at } 30 \mathrm{~cm} \text {-disturbed. }\end{array}$ \\
\hline
\end{tabular}




\begin{tabular}{|c|c|c|c|c|c|c|c|c|}
\hline IP\# & $\begin{array}{c}\text { ST \#/ SST } \\
\#\end{array}$ & $+/-$ & $\begin{array}{l}\text { Depth } \\
\text { (cmbs) }\end{array}$ & Munsell \& Color & Soil Texture & $\begin{array}{l}\text { Surface } \\
\text { Visibility }\end{array}$ & Setting Description & Shovel Test Comments \\
\hline 8 & MNHO3 & - & $0-25$ & $\begin{array}{c}\text { 10YR3/1 Very Dark } \\
\text { Gray }\end{array}$ & $\begin{array}{l}\text { Loamy Clay, } \\
\text { Moist, about } \\
20 \% \text { Redox }\end{array}$ & $0 \%$ & $\begin{array}{l}\text { About } 15 \mathrm{~m} \text { East of ROW. } \\
\text { Manicured grass next to fence. }\end{array}$ & $\begin{array}{l}\text { No cultural materials. Small } \\
\text { number of roots. No gravels. } \\
\text { Appears disturbed-top level } \\
\text { removed when landscape was } \\
\text { flattened due to pipeline. } \\
\text { Terminated due to clay. }\end{array}$ \\
\hline & & & $25-40$ & $\begin{array}{l}\text { 10YR5/2 Grayish } \\
\text { Brown, with 50\% } \\
\text { Redox }\end{array}$ & Clay, Moist & & & \\
\hline 9 & No Dig & - & & & & $0 \%$ & $\begin{array}{l}\text { Man-made lake. Tall wetland } \\
\text { grass bordering lake. }\end{array}$ & Lake \\
\hline 10 & ASB03 & - & $0-30$ & $\begin{array}{l}\text { 2.5Y7/1 Light Gray } \\
\text { mottled with } \\
\text { 10YR6/8 Brownish } \\
\text { Gray and 10YR4/1 } \\
\text { Dark Gray, } \\
\text { Disturbed }\end{array}$ & $\begin{array}{l}\text { Basal clay, } \\
\text { saturated }\end{array}$ & $5 \%$ & $\begin{array}{l}\text { Clear field with low grass. } \\
\text { Inbetween two man made } \\
\text { ponds. }\end{array}$ & $\begin{array}{l}\text { Over } 10 \% \text { black inclusions and } \\
\text { around } 7 \% \text { CaCO3. Large } \\
\text { percentage of mottling. And over } \\
7 \% \text { of fe oxidation with } \\
\text { concretions. No cultural materials. } \\
\text { Terminated at } 30 \mathrm{cmbs} \text {-disturbed. }\end{array}$ \\
\hline 11 & No Dig & - & & & & $0 \%$ & $\begin{array}{c}\text { Located on gravel road just South } \\
\text { of detention pond. }\end{array}$ & $\begin{array}{l}\text { No dig. Gravel road/detention } \\
\text { pond. }\end{array}$ \\
\hline 12 & MNHO4 & - & $0-35$ & $\begin{array}{l}\text { 10YR3/1 Very Dark } \\
\text { Gray, Heavily } \\
\text { disturbed }\end{array}$ & $\begin{array}{l}\text { Clay, Moist, } \\
\text { very mottled, } \\
\text { and about } \\
30 \% \text { Redox }\end{array}$ & $0 \%$ & $\begin{array}{l}\text { Just South of overgrown gravel } \\
\text { road. Ankle high grass. Nearby } \\
\text { fences, pond and ditch. }\end{array}$ & $\begin{array}{l}\text { Very distrubed. No cultural } \\
\text { materials. No gravels. No roots. } \\
\text { Terminated du to disturbed clay. }\end{array}$ \\
\hline
\end{tabular}




\begin{tabular}{|c|c|c|c|c|c|c|c|c|}
\hline IP\# & $\begin{array}{c}\text { ST \#/ SST } \\
\#\end{array}$ & $+/-$ & $\begin{array}{l}\text { Depth } \\
\text { (cmbs) }\end{array}$ & Munsell \& Color & Soil Texture & $\begin{array}{l}\text { Surface } \\
\text { Visibility }\end{array}$ & Setting Description & Shovel Test Comments \\
\hline 13 & ASB04 & - & $0-30$ & $\begin{array}{l}\text { 2.5Y7/1 Light Gray } \\
\text { mottled with } \\
\text { 10YR6/8 Brownish } \\
\text { Gray and 10YR4/1 } \\
\text { Dark Gray, } \\
\text { Disturbed }\end{array}$ & $\begin{array}{l}\text { Basal clay, } \\
\text { saturated, } \\
\text { with sand } \\
\text { inclusions }\end{array}$ & $5 \%$ & $\begin{array}{l}\text { Cleared field with low grass. } \\
\text { North of man-made pond }\end{array}$ & $\begin{array}{l}\text { Over } 10 \% \text { black inclusions and } \\
\text { around } 7 \% \text { CaCO3. Large } \\
\text { percentage of mottling. And over } \\
7 \% \text { of fe oxidation with } \\
\text { concretions and large percentage } \\
\text { of sand inclusions. No cultural } \\
\text { materials. Terminated at } 30 \text { cmbs- } \\
\text { disturbed. }\end{array}$ \\
\hline 14 & MNH05 & - & $0-40$ & $\begin{array}{l}\text { 10YR3/1 Very Dark } \\
\text { Gray, Heavily } \\
\text { mottled, disturbed }\end{array}$ & $\begin{array}{c}\text { Clay with sand } \\
\text { inclusions. } \\
\text { Moist with } \\
\text { about } 20 \% \\
\text { redox }\end{array}$ & $0 \%$ & $\begin{array}{l}\text { Cleared field with low grass. } \\
\text { Nearby man-made ponds (reason } \\
\text { for disturbance) }\end{array}$ & $\begin{array}{l}\text { Very disturbed. No culutral } \\
\text { materials. No gravels. No roots. } \\
\text { Hit water table at } 35 \mathrm{cmbs} \text {. } \\
\text { Terminated to to water table. }\end{array}$ \\
\hline 15 & ASB05 & - & $0-30$ & $\begin{array}{l}\text { 2.5Y7/1 Light Gray } \\
\text { mottled with } \\
\text { 10YR6/8 Brownish } \\
\text { Gray and 10YR4/1 } \\
\text { Dark Gray, } \\
\text { Disturbed }\end{array}$ & $\begin{array}{c}\text { Basal clay, } \\
\text { saturated, } \\
\text { compact with } \\
\text { sand } \\
\text { inclusions }\end{array}$ & $20 \%$ & $\begin{array}{c}\text { West of Southern water feature } \\
\text { in between two top soil piles. Tall } \\
\text { grass. }\end{array}$ & $\begin{array}{l}\text { Over } 10 \% \text { black inclusions and } \\
\text { around } 7 \% \text { CaCO3. Large } \\
\text { percentage of mottling. And over } \\
7 \% \text { of fe oxidation with } \\
\text { concretions and large percentage } \\
\text { of sand inclusions. No cultural } \\
\text { materials. Terminated at } 30 \text { cmbs- } \\
\text { disturbed. }\end{array}$ \\
\hline 16 & MNHO6 & - & $0-30$ & $\begin{array}{l}\text { 10YR3/1 Very Dark } \\
\text { Gray, Heavily } \\
\text { mottled, disturbed }\end{array}$ & $\begin{array}{c}\text { Clay with sand } \\
\text { inclusions. } \\
\text { Moist with } \\
\text { about } 20 \% \\
\text { redox }\end{array}$ & $0 \%$ & $\begin{array}{c}\text { Cleared field with low grass. } \\
\text { Nearby man-made ponds (reason } \\
\text { for disturbance) with slight rise in } \\
\text { elevation }\end{array}$ & $\begin{array}{l}\text { Very disturbed. No culutral } \\
\text { materials. No gravels. No roots. } \\
\text { Hit water table at } 35 \text { cmbs. } \\
\text { Terminated to to water table. }\end{array}$ \\
\hline
\end{tabular}




\begin{tabular}{|c|c|c|c|c|c|c|c|c|}
\hline IP\# & $\begin{array}{c}\text { ST \#/ SST } \\
\#\end{array}$ & $+/-$ & $\begin{array}{l}\text { Depth } \\
\text { (cmbs) }\end{array}$ & Munsell \& Color & Soil Texture & $\begin{array}{l}\text { Surface } \\
\text { Visibility }\end{array}$ & Setting Description & Shovel Test Comments \\
\hline 17 & No Dig & - & & & & $10 \%$ & $\begin{array}{c}6 \mathrm{ft} . \text { tall wetland grass, } \\
\text { inundated; knee high-water }\end{array}$ & $\begin{array}{l}\text { whole central area inaccessible } \\
\text { due to knee deep water. }\end{array}$ \\
\hline 18 & No Dig & - & & & & $10 \%$ & $\begin{array}{c}6 \mathrm{ft} . \text { tall wetland grass, } \\
\text { inundated; knee high-water }\end{array}$ & $\begin{array}{l}\text { whole central area inaccessible } \\
\text { due to knee deep water. }\end{array}$ \\
\hline 19 & No Dig & - & & & & $10 \%$ & $\begin{array}{c}6 \mathrm{ft} . \text { tall wetland grass, } \\
\text { inundated; knee high-water }\end{array}$ & $\begin{array}{l}\text { whole central area inaccessible } \\
\text { due to knee deep water. }\end{array}$ \\
\hline 20 & No Dig & - & & & & $10 \%$ & $\begin{array}{l}6 \mathrm{ft} \text {. tall wetland grass, } \\
\text { inundated; knee high-water }\end{array}$ & $\begin{array}{l}\text { whole central area inaccessible } \\
\text { due to knee deep water. }\end{array}$ \\
\hline 21 & No Dig & - & & & & $10 \%$ & $\begin{array}{c}6 \mathrm{ft} . \text { tall wetland grass, } \\
\text { inundated; knee high-water }\end{array}$ & $\begin{array}{l}\text { whole central area inaccessible } \\
\text { due to knee deep water. }\end{array}$ \\
\hline 22 & No Dig & - & & & & $10 \%$ & $\begin{array}{l}6 \mathrm{ft} \text {. tall wetland grass, } \\
\text { inundated; knee high-water }\end{array}$ & $\begin{array}{l}\text { whole central area inaccessible } \\
\text { due to knee deep water. }\end{array}$ \\
\hline 23 & No Dig & - & & & & $10 \%$ & $\begin{array}{c}6 \mathrm{ft} \text {. tall wetland grass, } \\
\text { inundated; knee high-water }\end{array}$ & $\begin{array}{l}\text { whole central area inaccessible } \\
\text { due to knee deep water. }\end{array}$ \\
\hline
\end{tabular}

